\title{
MARKET SELECTION FOR INTERNATIONAL REAL ESTATE INVESTMENTS
}

\author{
Heidi FALKENBACH \\ Helsinki University of Technology, Real Estate Research Group, P.O. Box 1200, \\ FIN-02015 TKK, Finland \\ E-mail: heidi.falkenbach@tkk.fi
}

Received 9 September 2009; accepted 16 October 2009

\begin{abstract}
This paper studies the market selection criteria in international real estate investments. It presents the results of a questionnaire study among internationally investing property investors in Europe. The results indicate that the most important factors for market selection are safety of property rights and title as well as expected return on property investments. Also other factors describing institutional set-up and market maturity were found to affect the market selection process, whereas the correlation of the property returns was not found to have a large impact on market selection.
\end{abstract}

KEYWORDS: Real estate; Investment; International investment; Market selection

\section{INTRODUCTION}

Investments markets are increasingly global - also for real estate. In Europe, the growth of cross border investments took of in the beginning of the $21^{\text {st }}$ century, during which the cross border investment volumes have grown from the $34 \%$ of the total investment volume in 2000 to $63 \%$ in 2007 (Jones Lang LaSalle, 2007). Even in 2008, when both the investment market turnover and average deal size fell sharply, the international investments still accounted for two-thirds of the investment volume (Jones Lang LaSalle, 2009).

In Europe, the three large property markets, UK, France and Germany, have traditionally dominated as target countries for international real estate investments. During the past years, the internationalization has, however, reached also the smaller markets in Europe. For example in the first half of 2008, only nine out of the 25 European countries monitored by CB Richard Ellis reported lower levels of international investment than $50 \%$ of the total transaction volume (CB Richard Ellis, 2008).

The purpose of this paper is to study, which criteria investors use for selecting the international markets they invest in. The research is conducted as a questionnaire survey among real estate investors, who have performed international property investments in Europe. Following this introductory section this paper is divided into four more sections. The second section reviews the literature on market selection. The third section discusses the questionnaire used in the survey as well as presents the respondent profiles. In the following section, the results from the questionnaire are discussed. The last section draws the conclusions. 


\section{LITERATURE REVIEW}

Surveys conducted among investors imply that the two main rationales for conducting international real estate investments are diversification benefits and possibilities to achieve higher returns for investments (Worzala, 1994; Newell and Worzala, 1995; Lima and Alencar, 2008; Falkenbach, 2009 and McAllister, 1999). Modern Portfolio Theory (Markowitz, 1952) suggests that investors base their allocation decisions on the expected return and risk of the investments, as well as diversification benefits, measured through the correlation of the returns with other assets in the portfolio. In international investments, the risk comprises of the variance of expected returns and currency risk.

The large body of literature focusing on the diversification benefits in indirect real estate investments in general confirms that international indirect property investments provide significant diversification benefits both in real-estate-only and mixed-asset portfolios and present optimal allocations for the studied countries (for a review, see Sirmans and Worzala, 2003).

The direct adaptability of the mean-variance analysis in international market selection is not straightforward even in the financial markets, where issues such as market familiarity, differing regulations and additional costs affect the selection of markets. The application of Modern Portfolio Theory to property investments has some general drawbacks due to the characteristics of property investments, such as large lot size and limited liquidity. In addition, different institutional set-ups and risks related to them, the localised nature of property investments, informational inefficiencies and investment management issues, among others, induce additional barriers to international property investments (Worzala, 1994; Newell and Worzala, 1995; Geurts and Jaffe, 1996; D'Arcy and Keogh, 1998; and McAllister, 1999), and thus suggest that a property inves- tor would apply additional criteria for choosing the markets they invest in.

The empirical research for identifying market selection criteria for international real estate investments has remained limited. Among the few ones is the questionnaire survey by Han (1996) conducted on U.S. pension real estate investment advisors. The survey focuses on the criteria used for selecting target markets, i.e. market selection in the case where the company utilises a top-down approach on market selection. According to the study, most respondents (91\%) who used a market targeting approach based their market selection of both quantitative and qualitative methods, and only two respondents (9\%) based their market selection only on quantitative methods. All respondents in the survey used economic factors of the potential market as criteria. Other popular criteria were real estate opportunities (95\%) demographic attributes (82\%) and market size (77\%). Quite surprisingly, portfolio diversification possibilities were mentioned as selection criteria only by less than half of the respondents. Other criteria mentioned in the survey were regional focus (27\%), company investment objectives (5\%), relative price levels (5\%) and operating efficiencies in different markets (5\%). In addition of generating target market lists, about a half of the investors also created lists of markets to avoid.

Ho et al. (2006) divide the factors affecting allocation decisions into macroeconomic factors (economic growth prospects) and real estate specific factors (office liquidity, market transparency and market vacancy). They use analytic hierarchy process (AHP) based of real estate investment expert judgment to identify the relative importance of these factors in real estate asset allocation decisions. Their analysis suggest that experts find economic growth prospects in the area to be the most important selection criteria, being equally or moderately preferred to liquidity and strongly preferred to market transparency and market vacancy. For 
the real estate specific factors, office liquidity is strongly preferred to market transparency and market vacancy, and market transparency is equally or moderately preferred to office market vacancy.

Chin et al. (2006) study the factors that are of importance in attracting local and international investments in Asian markets through a questionnaire survey on property consultants. The respondents were asked to rate seventeen factors, most of them describing the institutional set-up of the market, according to their importance ( $1=$ unimportant, $5=$ critical $)$ in attracting investments. Most respondents ranked all factors as important, very important or critical. The respondents regarded sound and financial economic structure, strength and stability of the economy, restrictions and regulations on foreign investors, political stability and legal regulation as the most important issues affecting the market attractiveness. The other factors that were found important were taxation, legal framework, liberalization of the financial market, currency stability and convertibility, the transparency of the legislative system, level of public infrastructure, market transparency, level or professionalism, government interventions, perceived corruption level and the urban form. The factor regarded as least important was the only non-institutional factor, i.e. cultural differences.

\section{METHODOLOGY AND RESPONDENT PROFILES}

The study was conducted as a questionnaire directed to internationally investing property investors who operate in Europe. The questionnaire included questions of the background of the respondent organisation and their portfolios as well as questions on international property investments. For questions in market selection, the respondents were given a list of 12 factors that could have an effect on the market selection. In addition to the given factors, the respondents could add other factors to the list, too. To increase understanding of the importance of the factors, the respondents were asked to mark, if the factor has to fill in certain criteria before investment in the country/market can even be considered for international investment, i.e. if the factor is considered a threshold factor. In addition, the respondents were asked to grade the importance of the factors in market attractiveness. If the factor in question had no effect on the market selection, the respondents were asked to mark that, too.

To obtain a higher rate of response for the questionnaire, the internationally investing investors were first approached by phone and e-mail, and invited to participate in the study. The contact information for the investors was received from Catella Property, a property transactions advisor operating in Europe. Altogether 60 companies were contacted, of whom 29 participated the study. Only 22 answers were, however, complete, and thus only these were included in the analysis. Figure 1 illustrates the respondent organisations by their country of origin. As can be seen, the sample is dominated by European, and especially Nordic investors.

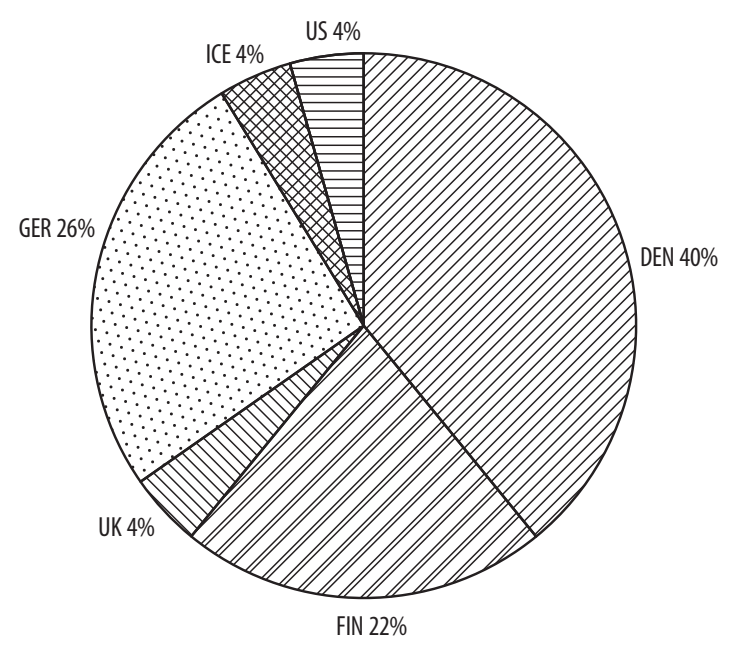

Figure 1. Respondents by their country of origin 
The aim in choosing the correct persons within the respondent organizations was to find persons, who prepare and make decisions on international allocations. Table 1 illustrates the respondents by their position in the respondent organizations. The sample is dominated investment managers (40\%) and managing directors (32\%). A rather large share of the respondents (14\%) were responsible of the acquisition teams. The group 'Other' includes two types of positions, managers of research activities (2 persons) and A vice president of company.

Table 1. Respondents by their position

\begin{tabular}{ll}
\hline Position $(\mathrm{n}=21)$ & Number \\
\hline Investment manager & 9 \\
Managing director & 7 \\
Acquisition manager & 3 \\
Other & 3 \\
\hline
\end{tabular}

As background information the investors were asked to indicate the approximate value of their total investment portfolio and property investment portfolio. The total value of investments managed by the respondent organisations was approximately 368 billion euros, the sizes of portfolio varying from ca. 200 million euros to 150 billion euros, the mean average portfolio size being 17 billion euros. Of the mean average portfolio almost $40 \%$ was allocated to property investments. The average figures are presented in Table 2.

The respondent profiles showed clear polarisation in regards to the relative allocation to property investments: as illustrated in Table $3,71 \%$ of the respondent organisations had a property allocation of equal or higher to $90 \%$ and $19 \%$ had an allocation of equal or less than $10 \%$ of the total portfolio. The remaining respondents had allocations of $20 \%$ and $70 \%$. The polarisation is explained by the different profiles of the companies, the organisations
Table 2. Assets under management and mean portfolios

\begin{tabular}{ll}
\hline & $€$ billion \\
\hline $\begin{array}{l}\text { Total value of asset under } \\
\text { management }(\mathrm{n}=22)\end{array}$ & 367,8 \\
$\quad \min$ & 0,2 \\
$\quad$ max & 150 \\
$\begin{array}{l}\text { Total value of property investment } \\
(\mathrm{n}=21)\end{array}$ & 140,7 \\
$\quad$ min & 0,1 \\
$\quad$ max & 59 \\
Allocation to property (\%) & 38 \\
Mean portfolio value & 16,7 \\
Mean property portfolio value & 6,7 \\
\hline
\end{tabular}

Table 3. Allocation to property investments

\begin{tabular}{ll}
\hline $\begin{array}{l}\text { Allocation to property investments } \\
(\mathrm{n}=21)\end{array}$ & Number \\
\hline $10 \%$ & 4 \\
$20 \%$ & 1 \\
$30 \%$ & \\
$40 \%$ & \\
$50 \%$ & \\
$60 \%$ & \\
$70 \%$ & \\
$80 \%$ & 1 \\
$90 \%$ & \\
$100 \%$ & 2 \\
\hline
\end{tabular}

having the smallest allocations being pension funds and the companies having largest allocations were either real estate investment companies or fund managers.

The respondents were also asked to indicate, how large a share of their property investments are allocated in foreign investments (see Table 4). The companies having allocation of $20-40 \%$, all had an allocation equal or below $25 \% .25 \%$ of the companies have an international allocation of $40-60 \%$ and $15 \%$ have an 
Table 4. Allocation to international property investments

\begin{tabular}{ll}
\hline $\begin{array}{l}\text { Allocation to international property } \\
(\mathrm{n}=20)\end{array}$ & Number \\
\hline $1-20 \%$ & 3 \\
$20-40 \%$ & 1 \\
$40-60 \%$ & 5 \\
$60-80 \%$ & 3 \\
$80-100 \%$ & 8 \\
\hline
\end{tabular}

international allocation of $60-80 \%$. As many as $40 \%$ of the respondents have an international allocation exceeding $80 \%$. The dominance of such high allocations to international property is surprising, as most of the literature on international real estate investments reports markedly smaller figures for international property investments. Thus, the sample seems to be biased towards investors with larger international allocations than in general and to companies focusing on international property investments.

The companies having the lowest allocations to international real estate were all pension funds, whereas in the other groups no pattern in regards to type of organization could be seen. Possible explanations to the relatively lower international allocations of pension funds could be national regulations as well as the pension fund's need to secure their domestic liabilities and hedge against domestic inflation.

To have a picture of the how diversified the investors' property portfolios are, the respondents were asked to indicate firstly, in how many continents and secondly, in how many European countries they had property investments. As defined when selecting the respondents, all respondents had property investments in Europe. Almost half of them had also investments in North America and almost $40 \%$ in Asia. As shown in Table 5, the investments in Australia and Africa as well as South-
America were less common, only $24 \%$ and $14 \%$ of the investors, respectively, had entered the continents. An interesting detail was, that in all cases the respondents had allocations in a less commonly entered market only if they had entered the more commonly entered markets (in Table 5: continents below the market in question. i.e. only those investors who had investments North-American market had investments in Asia, and only those investors who had investments in Asia, had investments in Australia and Africa).

Table 5. Respondents property investments of different continents

\begin{tabular}{ll}
\hline $\begin{array}{l}\text { Investment on different continents } \\
(\mathrm{n}=21)\end{array}$ & Number \\
\hline Europe & 21 \\
North-America & 10 \\
Asia & 8 \\
Australia & 5 \\
Africa & 5 \\
South-America & 3 \\
\hline
\end{tabular}

The range of diversification in the European portfolios could be divided to three groups (see Table 6). Almost one third of the investors had investments in five or less than five countries, half of them having investments only in two neighboring countries. A bit more than $40 \%$ of the investors had investments in six to 10 countries, and almost a third in more than 10 countries.

Table 6. Amount of different countries in the property portfolio $(n=21)$

\begin{tabular}{ll}
\hline $\begin{array}{l}\text { Number of European countries } \\
\text { in the portfolio }(\mathrm{n}=21)\end{array}$ & Number \\
\hline$\leq 5$ & 6 \\
$6-10$ & 9 \\
$\geq 11$ & 6 \\
\hline
\end{tabular}




\section{RESULTS OF THE QUESTIONNAIRE}

\subsection{Threshold factors for international real estate investments}

In the first part of the questionnaire, the respondents were asked to mark, which of the given factors are threshold factors, i.e. such factors that have to exceed a certain level before the investment in the market can even be considered by the investor. The threshold factors are illustrated in their rank order in Table 7.

The majority of investors considered the safety of title and property rights to be threshold factors, which is consistent with the research of Chin et al. (2006). Only two of the respondents did not regard them as threshold factors. A possible explanation for this is that both of these respondents operate in a very limited geographical area, where differences in these factors are not very high.

The expected return on property investments and expected economic growth in the area both reflect the return prospects of the property investments, even if the expected economic growth might also be regarded as a factor to evaluate risk, in terms of expected volatility of the demand for space. The expected return on property investments was chosen as a threshold factor by $80 \%$ of the investors, whereas the expected economic growth of the area was a threshold factor for ca. two thirds of the investors. The respondents, who did not regard the expected return on property investment as a threshold factor did neither regard the expected economic growth in the area as one. Taxation, which also affects the returns on the investments, was regarded as threshold factor by more then half of the respondents, as could be expected based on the study by Chin et al. (2006).

More than two thirds of the respondents regarded the liquidity of the property market and market size as threshold factors. These factors are in practice often discussed in pairs, as market size often directly affects the liquidity. Market size can, however also reflect e.g. availability of investment possibilities. In all but two cases the respondents who had chosen the one of them as a threshold factor also chose the other one, and vise versa.

The information barriers for international property investments are illustrated by the fact that half of the investors chose the availability of market information and performance benchmarks as a threshold factor. The same barrier could also be reflected in the selection

Table 7. Factors acting as threshold condition in market selection process

\begin{tabular}{llll}
\hline Factor & $\mathrm{n}$ & Threshold factor & $\%$ \\
\hline Safety of title/property rights & 21 & 19 & $90 \%$ \\
Expected return on property investments & 20 & 16 & $80 \%$ \\
Liquidity of property markets & 20 & 14 & $70 \%$ \\
Market size & 20 & 14 & $70 \%$ \\
Taxation & 21 & 14 & $67 \%$ \\
Availability of professional services in RE sector & 18 & 12 & $67 \%$ \\
Expected economic growth in the country/area & 20 & 13 & $65 \%$ \\
Availability of market information and performance benchmarks & 18 & 10 & $56 \%$ \\
Geographical nearness of markets to other target markets & 20 & 7 & $35 \%$ \\
Existence of indirect investment possibilities & 17 & 6 & $35 \%$ \\
Diversification possibilities through low correlation of returns & 17 & 4 & $24 \%$ \\
Existence of other foreign players in the market & 19 & 4 & $21 \%$ \\
\hline
\end{tabular}


of the availability of professional services as a threshold factor, but the importance of services probably also includes the need for outsourcing services in those companies, who do not start up local offices in the countries they invest in.

Less popular threshold factors were geographical nearness of other target markets, existence of indirect investment possibilities, diversification possibilities measured through low correlation of property returns and existence of other foreign players in the markets.

Other factors mentioned as threshold criteria were general transparency of the economy ( 1 respondent) and ethical consideration is terms of trade embargos between the countries (1 respondent).

\subsection{Factors not affecting the market selection}

The respondents were also given the possibility to mark those factors, which do not affect the selection of markets. These factors are illustrated in Table 8. The percentages in the Exhibit are calculated from the total population of respondents $(n=22)$.

One third of the respondents were of the opinion that the existence of indirect invest- ment possibilities and other foreign players in the market does not affect the selection of markets. The same applies for the geographical nearness of the other target markets. Quite surprisingly, $23 \%$ of the respondents did not regard availability of market information and performance benchmarks to be a factor that affects market selection.

An additional interesting factor is the effect of diversification possibilities through low correlation of returns on market selection: A large amount of the research on international real estate investments focuses on the analysis of diversification benefits. These analyses, conducted commonly by correlation analysis or portfolio optimization, rely on the assumption, that returns and their standard deviations as well as correlation structures drive the market selection. The factor was, however, chosen as a threshold factor by only one fourth of the respondents, and almost one fifth of the respondents indicate that the factor does not affect the market selection. This suggests that investors do not use as straightforward selection criteria as the theory assumes and thus supports the results of Han (1996).

Table 8. Factors that do not affect market selection

\begin{tabular}{lll}
\hline Factor & $\begin{array}{l}\text { Does not affect the } \\
\text { selection of markets }\end{array}$ & $\%$ \\
\hline Existence of indirect investment possibilities & 8 & $36 \%$ \\
Existence of other foreign players in the market & 8 & $36 \%$ \\
Geographical nearness of markets to other target markets & 7 & $32 \%$ \\
Availability of market information and performance benchmarks & 5 & $23 \%$ \\
Diversification possibilities through low correlation of returns & 4 & $18 \%$ \\
Availability of professional services in RE sector & 3 & $14 \%$ \\
Liquidity of property markets & 2 & $9 \%$ \\
Market size & 2 & $9 \%$ \\
Expected economic growth in the country/area & 2 & $9 \%$ \\
Safety of title/property rights & 1 & $5 \%$ \\
Expected return on property investments & 1 & $5 \%$ \\
Taxation & 1 & $5 \%$ \\
\hline
\end{tabular}




\subsection{Factors affecting the attractiveness of an investment market}

The respondents were given the same 12 factors and they were asked to evaluate how much each factor affects the attractiveness of a market in market selection. The evaluation was done on three-step conceptual scale (significantly - somewhat - not much). Table 9 summarizes the results. The factors are illustrated in rank order, which was created by weighting the factors by their importance (significantly $=3$ points, some what $=2$ points, not much $=1$ point).

In general, the factors having the most importance in the market selection are the same as those regarded as threshold factors. In the top three, respondents were fairly uniform in their responses, and they all regarded the factors having either a significant or medium impact. All respondents regarded the expected return on property investments to have a significant effect on the market selection. The second most important factor to affect market selection was the expected economic growth of the area, which was marked as a significantly affecting factor by two thirds of the respondents and as a factor having a medium impact by one third of the respondents. Also the safety of title was regarded as a significant factor by most of the respondents.

The deviation in responses increases with the rank order. After the factors that were regarded significant by most of the respondents, there is a group of factors (availability of professional services in real estate sector, taxation, liquidity of property markets, market size and availability of market information and performance benchmarks), which still are regarded significant by many of the respondents, but on the other hand do not have much effect on market selection for some investors. This would suggest that there would be some characteristics in the respondent profile that affect their attitude to the factor. For example the importance of the factors 'availability of professional services within the real estate

Table 9. Factors affecting the attractiveness of market

\begin{tabular}{|c|c|c|c|c|c|}
\hline \multirow[t]{2}{*}{ Factor } & \multirow[t]{2}{*}{$\mathrm{n}$} & \multicolumn{3}{|c|}{ Affects the attractiveness of market } & \multirow[t]{2}{*}{ Points } \\
\hline & & Significantly & Somewhat & Not much & \\
\hline Expected return on property investments & 18 & 18 & & & 54 \\
\hline Expected economic growth in the country/area & 18 & 12 & 6 & & 48 \\
\hline Safety of title/property rights & 16 & 15 & 1 & & 47 \\
\hline Availability of professional services in RE sector & 18 & 12 & 5 & 1 & 47 \\
\hline Taxation & 17 & 11 & 4 & 2 & 43 \\
\hline Liquidity of property markets & 17 & 10 & 6 & 1 & 43 \\
\hline Market size & 18 & 10 & 4 & 4 & 42 \\
\hline $\begin{array}{l}\text { Availability of market information and } \\
\text { performance benchmarks }\end{array}$ & 17 & 8 & 8 & 1 & 41 \\
\hline Existence of indirect investment possibilities & 15 & 4 & 5 & 5 & 27 \\
\hline $\begin{array}{l}\text { Diversification possibilities through low } \\
\text { correlation of returns }\end{array}$ & 13 & 4 & 4 & 5 & 25 \\
\hline $\begin{array}{l}\text { Geographical nearness of markets to other target } \\
\text { markets }\end{array}$ & 13 & 2 & 7 & 4 & 24 \\
\hline Existence of other foreign players in the market & 14 & 1 & 6 & 7 & 22 \\
\hline
\end{tabular}


sector' and 'availability of market information' might depend on the management strategy of the investors, as an investor recruiting local personnel has different needs than the one operating from e.g. other country.

An interesting group to look on is the factors with the lowest rankings. These factors have in common that not all investors ranked them at all and that the investor's opinions become more differentiated. For the existence of indirect investment possibilities, for example, each level of effect was selected by one third of the respondents. A possible explanation could be the difference is different investment strategies: An investor investing internationally indirectly would appreciate the availability of such instruments. On the other hand investors who have made the decision to invest only in direct real estate, would not be that interested of this option. Other possible explanation could be that some investors regard the existence of indirect investment possibilities as an indicator of market maturity or liquidity.

Also the effect of diversification possibilities through low correlation of returns on market attractiveness is interesting. As already discussed in the earlier section, the low correlations were not popular threshold factors and were often selected as factors not affecting the market selection at all. The effect on market attractiveness was more diverged, and the opinions were equally divided on the three options.

Geographical nearness of other target markets was not a popular threshold criterion, but is still a factor that clearly has some kind of an impact on the market selection. The existence of other foreign players in the target markets, on the other hand, was commonly regarded having a low importance.

\section{CONCLUSIONS}

This paper presented the results of questionnaire concerning the market selection for international real estate investments among investors operating in Europe. To increase the understanding of different factors' importance, the respondents were asked to indicate if the factors are threshold factors for market selection, if they have no effect on market selection or in case they have an effect, to evaluate the size of effect.

Even though diversification benefits are a major motivation factor for conducting international real estate investments, the correlation structures between countries does not seem to direct the market selection process. The results indicate the most important factors for market selection are the safety of title and property rights and the expected return of property. Also other institutional and market maturity factors were found to affect the market selection process. On factors regarding services on property markets and availability of indirect investment possibilities the responses were more diverged, which could be an indication of the management strategies of the investors affecting the market selection criteria, and could provide interesting insights for further research.

\section{ACKNOWLEDGEMENT}

The author wishes to acknowledge the Academy of Finland (project 122525) and Tekes - the National Technology Agency of Finland (project 40079/06) for the financial support.

\section{REFERENCES}

CB Richard Ellis (2008) Market View: European Investments, First Half 2008.

Chin,W., Dent, P. and Roberts, C. (2006) An exploratory analysis of barriers to investment and market maturity in Southeast Asian cities, Journal of Real Estate Portfolio Management, 12(1), pp. 49-58.

D'Arcy, E. and Keogh, G. (1998) Territorial competition and property market process: An exploratory analysis, Urban Studies, 35(8), pp. 1215-1230. doi:10.1080/0042098984330 
Falkenbach, H. (2009) Diversification benefits in the Finnish commercial property market, International Journal of Strategic Property Management, 13(1), pp. 23-35.

doi:10.3846/1648-715X.2009.13.23-35

Geurts, T.G. and Jaffe, A.J. (1996) Risk and real estate investment: An international perspective, Journal of Real Estate Research, 11(2), pp. 117-130.

Han, J. (1996) Targeting markets is popular: A survey of pension real estate investment advisors, Real Estate Finance, 13(1), pp. 66-75.

Ho, K. H., Ong, S.E. and T.F. Sing, (2006) Asset allocation: International real estate investment strategy under a workable analytic hierarchy process (AHP), Journal of Property Investment and Finance, 24(4), pp. 324-342. doi:10.1108/14635780610674516

Jones Lang LaSalle (2007) European Capital Market Bulletin 2007, Market Report.

Jones Lang LaSalle (2009) Retail Real Estate investment activity in Continental Europe down 56\%, Press Release 12.1.2009.

Lima, J.R. Jr. and Alencar, C.T. (2008) Foreign investment and the Brazilian real estate mar- ket, International Journal of Strategic Property Management, 12(2), pp. 109-123. doi:10.3846/1648-715X.2008.12.109-123

Markowitz, H.M. (1952) Portfolio selection, The Journal of Finance, 7(1), pp. 77-91. doi:10.2307/2975974

McAllister, P. (1999) Globalization, integration and commercial property. Evidence from the UK, Journal of Property Investment and Finance, 17(1), pp. 8-26. doi:10.1108/14635789910252774

Newell, G. and Worzala, E. (1995) The role of international property in investment portfolios, Journal of Property Finance, 6(1), pp. 55-63. doi:10.1108/09588689510088186

Sirmans, C.F. and Worzala, E. (2003) International direct real estate investment: A review of the literature, Urban Studies, 40(5-6), pp. 10811114. doi:10.1080/0042098032000074335

Worzala, E. (1994) Overseas property investments: how are they perceived by the institutional investor? Journal of Property Valuation and Investment, 12(3), pp. 31-47. doi:10.1108/14635789410063904

\section{SANTRAUKA}

\section{RINKOS PASIRINKIMAS TARPTAUTINĖMS INVESTICIJOMS I NEKILNOJAMĄJİ TURTĄ}

\section{Heidi FALKENBACH}

Šiame darbe nagrinèjami kriterijai, pagal kuriuos pasirenkamos rinkos tarptautinèms investicijoms i nekilnojamaji turta. Jame pateikiami Europos nekilnojamojo turto investuotojų, investuojančių tarptautiniu mastu, apklausos rezultatai. Rezultatai rodo, kad svarbiausi veiksniai, renkantis rinka, yra nuosavybès teisiu saugumas ir laukiama graža iš investicijų i nekilnojamaji turta. Nustatyta, kad rinkos pasirinkimo procese svarbūs ir kiti veiksniai, apibūdinantys institucinę sąrangą ir rinkos branduma, o nekilnojamojo turto grąžos koreliacija rinkai pasirinkti reikšmingos ittakos neturi. 